\title{
ANALISIS PERANAN SEKTOR INDUSTRI TERHADAP PEREKONOMIAN JAWA TENGAH TAHUN 2000 DAN TAHUN 2004 (ANALISIS INPUT OUTPUT)
}

\author{
Didit Purnomo ${ }^{1}$ \\ Devi Istiqomah ${ }^{1}$ \\ ${ }^{1}$ Fakultas Ekonomi Universitas Muhammadiyah Surakarta \\ E-mail: didiet_p@yahoo.com
}

\begin{abstract}
This research aim to analyse role of industrial sector to other economy sectors in Central Java and the role in Central Java economy. Research method, which applied that, is Input Output Analysis Model (Analysis I-O), accompanied by analysis of role of production sector and output creator of Central Java economy, backward and forward linkage index analysis, and key sector analysis. Data which used that is I-O table of Central Java year 2000 and year 2004 with classification 19 sector is obtained from Central Java BPS. Research result indicate that industrial sector role is seen enough dominant in Central Java economy in the year 2000 and 2004. From the result, author suggests government so that more give priority to industrial sectors that become key sector in Central Java in the year 2000 and 2004.
\end{abstract}

Keywords: backward and forward linkage, key sector

\section{PENDAHULUAN}

Sejak terjadinya krisis ekonomi yang mulai dirasakan sejak bulan Juni 1997, membuat pembangunan ekonomi di Indonesia mengalami stagnasi, bahkan di beberapa bidang mengalami kemunduran. Dalam menghadapi era globalisasi dan perdagangan bebas, Indonesia dituntut untuk siap bersaing dengan negara-negara lain. Agar bisa bersaing dengan negara lain, sebelumnya Indonesia harus memantapkan terlebih dahulu perekonomian yang goncang akibat krisis multidimensi yang berkepanjangan. Fundamental perekonomian yang kuat akan meningkatkan kesiapan pemerintah dalam menghadapi era globalisasi. Pembangunan ekonomi secara nasional tidak bisa terlepas dari pembangunan ekonomi secara regional.

Pada hakekatnya pembangunan regional merupakan pelaksanaan dari pembangunan nasional pada wilayah tertentu yang disesuaikan dengan kemampuan fisik, sosial ekonomi regional tersebut, serta harus tunduk pada peraturan tertentu. Demi keberhasilan pembangunan ekonomi regional itulah, maka pemerintah memberlakukan otonomi daerah.

Otonomi daerah merupakan kewenangan daerah otonomi untuk mengatur dan mengurus kepentingan masyarakat setempat menurut prakarsa sendiri berdasarkan aspirasi masyarakat. Ini karena daerah akan diberi peran yang lebih besar melalui penyerahan 
semua urusan pemerintahan serta sumbersumber keuangannya, kecuali kewenangan dalam politik politik luar negeri, pertahanan keamanan, peradilan, moneter dan fiskal, agama dan perencanaan sosial. Ketidakmampuan keuangan pusat akibat krisis ekonomi, mengakibatkan daerah diberikan wewenang untuk mencari sumber-sumber pendapatan dan mengurus kebutuhan sendiri agar beban pusat menjadi berkurang.

Menurut Kamaluddin (1987:46), maksud dan tujuan yang hakiki dari otonomi daerah dan desentralisasi daerah adalah:

1. Mengurangi beban pemerintah pusat dan campurtangannya tentang masalah-masalah tingkat lokal atau daerah di samping itu memberi peluang untuk koordinasi pelaksanaan pada tingkat lokal tersebut.

2. Meningkatkan pengertian serta dukungan pusat dalam kebutuhan usaha pembangunan daerah.

3. Penyusunan program-program pembangunan untuk perbaikan dan penyempurnaan sosial ekonomi pada tingkat lokal akan menjadi realistis.

4. Melatih dan mengajar masyarakat untuk bisa mengatur dan mengatur rumah tangganya.

5. Terciptanya pembinaan dan pengembangan daerah dalam rangka kesatuan nasional.

Di era otonomi daerah ini setiap wilayah atau daerah dituntut untuk bisa mencari, mengelola dan mengidentifikasi kemampuan daerah bersangkutan. Untuk itu perlu adanya perencanaan pembangunan yang tepat dengan memperhatikan potensi ekonomi yang dimilikinya.

Pertumbuhan ekonomi Jawa Tengah tahun 2005 yang ditunjukkan oleh laju per- tumbuhan Produk Domestik Regional Bruto (PDRB) atas dasar harga konstan 2000, semakin membaik dari tahun sebelumnya, yaitu 5,35 persen $(2004=5,13 \%)$. Hal cukup beralasan mengingat kondisi perekonomian relatif terus membaik selama tahun 2001 sampai tahun 2005.

Sedangkan, saat ini perekonomian Provinsi Jawa Tengah terus mengalami pertumbuhan, yaitu pada tahun 2003 (4,98 persen), tahun 2004 (5,13 persen) dan tahun 2005 (5,43 persen). Pertumbuhan ekonomi Provinsi Jawa Tengah mengandalkan berbagai sektor antara lain Pertanian (5,33 persen), Pertambangan (2,73 persen), Industri $(6,41$ persen), Listrik, Gas, dan Air Bersih (8,65 persen), Gedung (7,84 persen), Perdagangan, Hotel, dan Restoran (2,63 persen), Transportasi dan Komunikasi (4,67 persen), Keuangan (2,67 persen), dan Jasa (5,58 persen). Sebagai cara untuk mendorong pertumbuhan ekonomi yang signifikan, menciptakan lapangan kerja, mengurangi kemiskinan, dan meningkatkan kesejahteraan penduduk, Pemerintah Daerah Provinsi Jawa Tengah mentargetkan komposisi investasi dari Pemerintah Daerah sebesar 25 persen dan investasi swasta sebesar 75 persen (BPS Jawa Tengah, 2006).

Untuk mencapai tujuan dan sasaran pembangunan dan daerah, khususnya pembangunan ekonomi di Jawa Tengah dan untuk dapat memanfaatkan sumberdaya ekonomi daerah secara optimal, maka pembangunan daerah dapat disusun menurut tujuan antar sektor. Perencanaan sektoral dimaksudkan untuk pengembangan sektor-sektor tertentu disesuaikan dengan keadaan dan potensi masing-masing sektor dan juga tujuan pembangunan yang ingin dicapai. 
Dengan menggunakan Tabel InputOutput (I-O) Jawa Tengah tahun 2000 dan 2004 akan dijabarkan sektor-sektor yang menjadi sektor industri di Jawa Tengah. Selanjutnya diharapkan dapat dipakai sebagai informasi yang komprehensif agar tepat guna dan tepat sasaran bagi perekonomian Jawa Tengah.

Pembangunan ekonomi daerah adalah suatu proses dimana pemerintah daerah mengelola sumberdaya-sumberdaya yang ada membentuk suatu pola kemitraan antara pemerintah daerah dengan sektor swasta untuk menciptakan suatu lapangan kerja baru dan merangsang perkembangan kegiatan ekonomi (pertumbuhan ekonomi) dalam wilayah tersebut (Arsyad, 1999)

Untuk mempercepat pengembangan perekonomian daerah, maka perlu memperbesar penanaman investasi pada lapangan usaha yang memiliki keterkaitan yang besar terhadap lapangan usaha lainnya. Dengan demikian akan dapat mendorong lapangan usaha lainnya yang mendukung lapangan usaha yang dijadikan kunci atau leading tersebut, sehingga akan bisa meningkatkan produksi regional secara keseluruhan melalui dampak multipliernya. (Ropingi dan Dany Artanto, 2002).

Industrialisasi merupakan suatu proses interaksi antara pengembangan teknologi, inovasi spesialisasi, dalam produksi dan perdagangan antarnegara yang pada akhirnya sejalan dengan peningkatan pendapatan perkapita mendorong perubahan struktur ekonomi. Industrialisasi sering juga diartikan sebagai suatu proses modernisasi ekonomi yang mencakup semua sektor ekonomi yang mencakup semua ekonomi yang ada yang terkait langsung maupun tidak langsung dengan industri manufaktur. Walaupun sangat penting bagi kelangsungan pertumbuhan ekonomi, industrialisasi itu sendiri bukan tujuan akhir, melainkan hanya merupakan salah satu strategi yang harus ditempuh untuk mendukung proses pembangunan ekonomi guna mancapai tingkat pendapatan perkapita yang tinggi (Tambunan, 2001)

Industri mempunyai peranan sebagai sektor pemimpin maksudnya dengan adanya pembangunan industri maka akan memacu dan mengangkat pembangunan sektor-sektor lainnya seperti sektor pertanian dan jasa. Sebagai misal pertumbuhan sektor industri yang pesat akan merangsang pertumbuhan sektor pertanian untuk menyediakan bahanbahan baku bagi suatu industri. Dengan adanya industri tersebut memungkinkan juga berkembangnya sektor jasa.

Menurut Hirschman, pertumbuhan yang cepat dari satu atau beberapa industri mendorong perluasan industri-industri lainnya yang terkait dengan sektor industri yang tumbuh lebih dulu. Dalam sektor produksi mekanisme pendorong pembangunan (inducement mechanisme) yang tercipta sebagai akibat dari adanya hubungan antara berbagai industri dalam menyediakan barang-barang yang digunakan sebagai bahan mentah bagi industri lainnya, dibedakan menjadi dua macam yaitu pengaruh keterkaitan ke belakang (backward linkage effect) dan pengaruh keterkaitan ke depan (forward linkage effect). Pengaruh keterkaitan ke belakang maksudnya tingkat rangsangan yang diciptakan oleh pembangunan suatu industri terhadap perkembangan industri lainnya. Sedangkan pengaruh keterkaitan ke depan adalah tingkat rangsangan yang dihasilkan oleh industri yang pertama bagi input mereka (Arsyad, 1999). 


\section{METODE PENELITIAN}

\section{Data dan Sumber Data}

Data yang dipergunakan dalam penelitian ini adalah data sekunder yaitu Tabel Input Output perekonomian Jawa Tengah tahun 2000 dan Tahun 2004. Tabel input output disajikan dalam bentuk matriks yang diklasifikasikan menjadi 19 sektor perekonomian. Data tabel input output perekonomian Jawa Tengah tahun 2000 dan tahun 2004 diperoleh dari Badan Pusat Statistik Jawa Tengah dan dari instansi terkait lainnya.

\section{Metode dan Alat Analisis Data}

Metode analisis data yang digunakan dalam penelitian ini adalah Model Input-Output. Model input-output pertama kali dikembangkan oleh Wassily Leontief pada tahun 1930an. Idenya sangat sederhana namun mampu menjadi salah satu alat analisis yang ampuh dalam melihat hubungan antarsektor dalam perekonomian (Nazara, 1997:48). Komponen yang paling penting dalam analisis input output adalah inverse matriks tabel input output, yang sering disebut sebagai inverse Leontif (Miller, 1999:15). Matriks ini mengandung informasi penting tentang bagaimana kenaikan produksi dari suatu sektor (industri) akan menyebabkan berkembangnya sektor-sektor lainnya. Matriks kebalikan Leontif merangkum seluruh dampak dari perubahan produksi suatu sektor terhadap total produksi sektorsektor lainya ke dalam koefisien-koefisien yang disebut sebagai multiplier ( $\alpha \mathrm{ij})$. Multiplier ini adalah angka-angka yang terlihat di dalam matriks (1-A)-1. Adapun analisis yang akan dihitung dalam penelitian ini adalah sebagai berikut: a. Analisis Keterkaitan ke Depan.

b. Analisis Keterkaitan ke Belakang.

c. Analisis Sektor Kunci Menggunakan Forward dan Backward Process.

\section{Konsep Dasar Input Output}

Jhingan (1996:751) menyebutkan bahwa analisis input output juga merupakan variasi terbaik keseimbangan umum yang mempunyai tiga unsur utama. Pertama, melalui analisis input output memusatkan perhatiannya pada perekonomian dalam keadaan seimbang. Kedua, tidak memusatkan perhatian pada analisis permintaan tetapi masalah teknis produksi. Ketiga, analisis ini didasarkan pada penelitian empiris.

Ada beberapa manfaat yang dapat diperoleh dari penggunaan model input output. Pertama, melalui model ini dapat diperkirakan dampak permintaan akhir terhadap output, nilai tambah, impor, penerimaan pajak dan kesempatan kerja yang ditawarkan diberbagai sektor produksi yang ada. Kedua, sektor-sektor yang pengaruhnya paling dominan terhadap pertumbuhan ekonomi dan sektor-sektor yang paling peka terhadap perekonomian dapat diketahui melalui analisis input output. Ketiga, model input output juga dapat digunakan untuk melihat komposisi penyediaan dan penggunaan barang dan jasa, terutama dalam analisis terhadap kebutuhan impor dan kemungkinan subtitusinya. Keempat, dengan menggunakan model ini dapat dilihat konsistensi dan kelemahan berbagai data statistik yang pada gilirannya dapat dijadikan sebagai landasan perbaikan, penyempurnaan dan pengembangan lebih lanjut. Kelima, penyusunan proyeksi variabel-variabel ekonomi makro dapat dilakukan dengan memanfaatkan model input output. Keenam, model ini berguna dalam mengana- 
lisis perubahan harga yang dapat ditinjau dari pengaruh secara langsung dan tidak langsung dalam perubahan harga input terhadap harga output (Tabel Input Output Indonesia, 2000:5).

Suatu tabel input output menyajikan informasi tentang transaksi barang dan jasa yang terjadi pada semua sektor yang ada dalam perekonomian, dengan bentuk penyajian berupa matriks. Dalam suatu Tabel Input Ouput yang bersifat terbuka dan statis, transaksi yang digunakan dalam penyusunan tabel input output harus memenuhi tiga asumsi dasar, yaitu (Tabel Input Output Indonesia, 2000:3):

1. Keseragaman (homogeneity), yaitu asumsi bahwa setiap sektor ekonomi hanya memproduksi satu jenis barang dan jasa dengan susunan input tunggal (seragam) dan tidak ada subtitusi otomatis terhadap input dari sektor yang berbeda.

2. Kesebandingan (proportionality), yaitu asumsi bahwa hubungan antara input dan ouput pada setiap sektor produksi merupakan fungsi linier, artinya kenaikan dan penurunan output suatu sektor akan sebanding dengan kenaikan dan penurunan input dari sektor yang bersangkutan.

3. Penjumlahan (additivity), yaitu asumsi bahwa total efek dari kegiatan produksi di berbagai sektor merupakan penjumlahan dari efek pada masing- masing kegiatan.

Berdasarkan asumsi tersebut, maka tabel input output sebagai model kuantitatif memiliki keterbatasan, yaitu bahwa koefisien input atau koefisien teknis diasumsikan tetap (konstan) sepanjang periode analisis atau proyeksi. Maka produsen tidak dapat menyesuaikan perubahan-perubahan inputnya atau mengubah proses produksi. Karena koefisien teknis dianggap konstan, maka teknologi yang digunakan oleh sektor-sektor ekonomi dalam proses produksi pun dianggap konstan. Akibatnya perubahan kuantitas dan harga input akan selalu sebanding dengan perubahan kuantitas dan harga output. Walaupun mengandung keterbatasan, model input ouput tetap merupakan alat analisis ekonomi yang lengkap dan komprehensip (Tabel I-O Indonesia, 2000:3).

Pada Tabel 1 disajikan contoh Tabel I-O untuk sistem perekonomian yang terdiri dari tiga sektor produksi yaitu sektor 1, 2, dan 3 .

Dari gambaran tersebut tampak bahwa penyusunan angka-angka dalam bentuk matriks memperlihatkan suatu jalinan yang saling kait dari berbagai kegiatan antarsektor. Sebagai ilustrasi dapat diamati proses

Tabel 1. Bagan Tabel Input Output Sistem Perekonomian dengan Tiga Sektor Produksi

\begin{tabular}{|c|c|c|c|c|c|c|c|}
\hline \multirow{2}{*}{\multicolumn{2}{|c|}{$\begin{array}{l}\text { Alokasi Output Input } \\
\text { Antara }\end{array}$}} & & \multicolumn{3}{|c|}{ Permintaan Antara Sektor Produksi } & \multirow{2}{*}{$\begin{array}{l}\text { Permintaan } \\
\text { Akhir }\end{array}$} & \multirow{2}{*}{$\begin{array}{l}\text { Jumlah } \\
\text { Output }\end{array}$} \\
\hline & & & 1 & 2 & 3 & & \\
\hline \multirow{3}{*}{$\begin{array}{l}\text { Input } \\
\text { Antara }\end{array}$} & \multirow{3}{*}{$\begin{array}{l}\text { Sektor } \\
\text { Produksi }\end{array}$} & 1 & $X_{11}$ & $X_{12}$ & $X_{13}$ & $\mathrm{~F}_{1}$ & $X_{1}$ \\
\hline & & 2 & $X_{21}$ & $X_{22}$ & $X_{23}$ & $\mathrm{~F}_{2}$ & $x_{2}$ \\
\hline & & 3 & $X_{31}$ & $X_{32}$ & $X_{33}$ & $\mathrm{~F}_{3}$ & $X_{3}$ \\
\hline \multicolumn{3}{|c|}{ Input Primer } & $V_{1}$ & $\mathrm{~V}_{2}$ & $V_{3}$ & & \\
\hline \multicolumn{3}{|c|}{ Jumlah Input } & $X_{1}$ & $\mathrm{X}_{2}$ & $X_{3}$ & & \\
\hline
\end{tabular}


pengalokasian output pada Tabel 1 Output sektor 1 pada tabel tersebut adalah sebesar $\mathrm{X}_{1}$ dan didistribusikan sepanjang baris sebesar $\mathrm{X}_{11}, \mathrm{X}_{12}$, dan $\mathrm{X}_{13}$ masing-masing untuk memenuhi permintaan antara sektor 1 , 2, dan 3, sedangkan sisanya sebesar F1 digunakan untuk memenuhi permintaan akhir.

Begitu juga dengan output sektor 2 dan 3 masing-masing sebesar $\mathrm{X}_{2}$ dan $\mathrm{X}_{3}$, dapat dilihat dengan cara yang sama dalam proses pengalokasian output sektor 1 (Tabel I-O DKI Jakarta, 2000:65).

\section{Cara Perhitungan}

$$
\begin{aligned}
& \mathrm{X}_{11}+\mathrm{X}_{12}+\ldots+\mathrm{X}_{1 \mathrm{j}} \ldots+\mathrm{X}_{1 \mathrm{n}}+\mathrm{F}_{1}+\mathrm{E}_{1}= \\
& \mathrm{X}_{1}+\mathrm{M}_{1} \\
& \mathrm{X}_{21}+\mathrm{X}_{22}+\ldots+\mathrm{X}_{2 \mathrm{j}} \ldots+\mathrm{X}_{2 \mathrm{n}}+\mathrm{F}_{2}+\mathrm{E}_{2}= \\
& \mathrm{X}_{2}+\mathrm{M}_{2} \\
& \mathrm{X}_{\mathrm{i} 1}+\mathrm{X}_{\mathrm{i} 2}+\ldots+\mathrm{X}_{\mathrm{ij}} \ldots+\mathrm{X}_{\mathrm{in}}+\mathrm{Fi}_{\mathrm{i}}+\mathrm{Ei}_{\mathrm{i}}= \\
& \mathrm{X}_{\mathrm{i}}+\mathrm{M}_{3} \\
& X_{n 1}+X_{n 2}+\ldots .+X_{n J}+\ldots+X_{n n}+F_{n}+E_{n}= \\
& \mathrm{X}_{\mathrm{n}}+\mathrm{Mn}_{\mathrm{n}}
\end{aligned}
$$

Di sini $X_{\mathrm{ij}}$ adalah jumlah output sektor $i$ yang diminta sektor $j$ sebagai input bagi produksi output sektor $\mathrm{j}$ (permintaan antara), Fi adalah permintaan akhir domestik terhadap output sektor $i, E i$ adalah ekspor atau permintaan akhir luar negeri atau daerah, $X_{i}$ adalah total sektor $i$ dan $M i$ adalah jumlah sektor $i$. Dengan mensubstitusikan $X_{\mathrm{ij}}$ maka persamaan (1) di atas akan menjadi:

$\mathrm{a} 11 \mathrm{X}_{1}+\mathrm{a}_{12} \mathrm{X}_{2}+\ldots+\mathrm{a} 1 \mathrm{j} \mathrm{Xj}_{\mathrm{j}} .+\mathrm{a} 1 \mathrm{n} \mathrm{Xn}_{\mathrm{n}}+\mathrm{F}_{1}+$ $\mathrm{E}_{1}=\mathrm{X}_{1}+\mathrm{M}_{1} \mathrm{a}_{21} \mathrm{X}_{1}+\mathrm{a}_{22} \mathrm{X}_{2}+\ldots+\mathrm{a}_{2 j} \mathrm{Xj}_{j} \ldots+$ $\mathrm{a}_{2 n} \mathrm{Xn}_{\mathrm{n}}+\mathrm{F}_{2}+\mathrm{E}_{2}=\mathrm{X}_{2}+\mathrm{M}_{2} \mathrm{ai}_{1} \mathrm{X}_{1}+\mathrm{ai}_{2} \mathrm{X}_{2}+\ldots$ $+\operatorname{aij}_{\mathrm{j}} \ldots+$ ain $\mathrm{Xn}_{n}+\mathrm{Fi}_{\mathrm{i}}+\mathrm{Ei}_{\mathrm{i}}=\mathrm{X}_{\mathrm{i}}+\mathrm{Mi}_{\mathrm{i}}$
$\mathrm{An}_{1} \mathrm{X}_{1}+\operatorname{an}_{2} \mathrm{X}_{2}+\ldots+\operatorname{anj} \mathrm{Xj}_{\mathrm{j}} \ldots+\mathrm{ann}_{\mathrm{X}}+\mathrm{Fn}_{n}+$ $\mathrm{En}_{\mathrm{n}}=\mathrm{X}_{\mathrm{n}}+\mathrm{Mn}_{\mathrm{n}}$

Persamaan (2) disederhanakan ke dalam persamaan matriks menjadi sebagai berikut:

$A x+F+E=X+M$

dimana

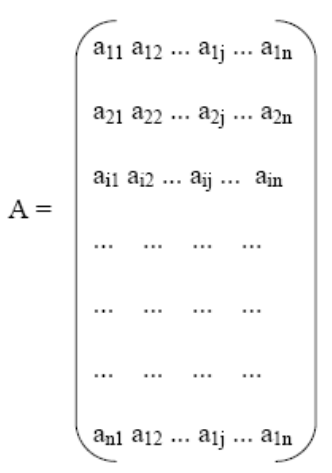

A disebut matriks koefisien teknologi, matrik yang menunjukkan technological input structure antarsektor perekonomian $a_{i j}$ dibaca sebagai jumlah output sektor $i$ yang dibutuhkan sektor $j$ untuk memproduksi satu unit output sektor $j(X i j / X j)$.

Persamaan (3) di atas adalah persamaan identitas untuk analisis input output dengan perlakuan impor secara kompetitif. Impor setiap sektor ekonomi dianggap proporsional terhadap tingkat konsumsi domestik terhadap output sektor tersebut. Misalnya ditentukan proporsi ini sebagai koefisien import, maka koefisien suatu sektor ekonomi dapat dihitung sebagai berikut:

$$
\mu=\frac{\text { impor }}{\text { permintaan antara }+ \text { permintaan akhir }}
$$

atau

$$
\mu=\frac{M}{\sum X_{i j}+F} \text { sehingga } \mu_{i}=\left(\sum X_{i j}+F\right)
$$


Dengan demikian persamaan $A X+F+E=$ $X+M$ dapat diubah menjadi:

$\mathrm{X}=\mathrm{AX}+\mathrm{F}+\mathrm{E}-\mu \mathrm{AX}-\mu \mathrm{F}$

Selanjutnya suku yang mengandung $\mathrm{X}$ dipindahkan ke sebelah kiri tanda persamaan, menjadi:

$X-A X+\mu A X=F-\mu F+E$

$[\mathrm{I}-(\mathrm{I}-\mu) \mathrm{A}] \mathrm{X}=(\mathrm{I}-\mu) \mathrm{F}+\mathrm{E}$

Maka X dalam persamaan (4) di atas berubah menjadi:

$X=[I-(I-\mu) A]^{-1}[(I-\mu) F+E]$

$\mathrm{X}=[\mathrm{I}-(\mathrm{I}-\mu) \mathrm{A}]^{-1}$ adalah invers yang digunakan dalam analisis seperti diketahui dari persamaan (7) persamaan ini terbentuk dari dua bagian:

$\mathrm{X}=[\mathrm{I}-(\mathrm{I}-\mu) \mathrm{A}]^{-1}(\mathrm{I}-\mu) \mathrm{F}$, tanpa dengan ekspor

$\mathrm{X}=[\mathrm{I}-(\mathrm{I}-\mu) \mathrm{A}]^{-1} \mathrm{E}$, hanya ekspor

$\mathrm{X}=\mathrm{AX}+\mathrm{F}+\mathrm{E}$

Selanjutnya suku yang mengandung matriks $X$ dipindahkan ke sebelah kiri tanda persamaan:

$$
\begin{aligned}
& X-A X=F+E \\
& (I-A) X=F+E
\end{aligned}
$$

Maka $X$ dalam persamaan (4) berubah menjadi:

$X=(I-A)^{-1}(F+E)$
$(I-A)^{-1}$ adalah invers matriks leontief, (I $A)^{-1} F$ adalah output yang disebabkan oleh domestik (Final Demand) dan $(I-A)^{-1} E$ adalah output yang disebabkan oleh ekspor (Foreign Final Demand). Domestik Final Demand biasanya terdiri dari elemen konsumsi rumah tangga, pengeluaran pemerintah, dan investasi. Matriks Inverse Leontief sering dilambangkan sebagai $B$, dengan elemen matriknya $b_{i j}$ dibaca sebagai besarnya output sektor $i$ yang disebabkan oleh permintaan di sektor $j$ sebesar satu unit.

\section{Analisis Data dengan Matriks Inverse Leontief}

1. Analisis Indeks Total Keterkaitan

Indeks total keterkaitan digunakan sebagai dasar perumusan strategi pembangunan ekonomi dengan melihat keterkaitan antar sektor dalam suatu sistem perekonomian. Menurut Rasmussen indeks total keterkaitan meliputi indeks total keterkaitan ke belakang dan indeks total keterkaitan ke depan. Indeks total keterkaitan ke belakang suatu industri atau suatu sektor menunjukkan hubungan keterkaitan tentang pengaruh yang ditimbulkan oleh satu unit permintaan akhir pada sektor tersebut terhadap total pembelian input semua sektor di dalam suatu perekonomian.

Indeks total keterkaitan ke depan menunjukkan hubungan keterkaitan tentang pengaruh yang ditimbulkan oleh satu unit permintaan akhir suatu sektor terhadap total penjualan output semua sektor di dalam suatu perekonomian.

\section{Indeks Total Keterkaitan ke Belakang}

Konsep ini diartikan sebagai kemampuan suatu sektor untuk meningkatkan pertumbuhan industri hulunya. Indeks total keterkaitan 
ke belakang disebut juga sebagai indeks daya penyebaran (power of dispersion) yang digunakan untuk mengukur kaitan ke belakang. Rumus untuk mencari nilai indeks total keterkaitan ke belakang yaitu:

$$
\mathrm{BL}_{\mathrm{j}}=\frac{\mathrm{n} \sum_{\mathrm{i}=1}^{\mathrm{n}} \mathrm{b}_{\mathrm{ij}}}{\sum_{\mathrm{i}=1}^{\mathrm{n}} \sum_{\mathrm{j}=1}^{\mathrm{n}} \alpha_{\mathrm{ij}}}
$$

dimana:

$B L j=$ indeks total keterkaitan ke belakang sektor $j$

$\alpha i j=$ unsur matriks kebalikan Leontief

Besaran $B L j$ dapat mempunyai nilai sama dengan 1, lebih besar 1 atau lebih kecil 1 . Bila $B L j=1$ hal tersebut berarti bahwa daya penyebaran sektor $j$ sama dengan rata-rata penyebaran seluruh sektor ekonomi. Bila $B L j$ $>1$ hal tersebut berarti daya penyebaran sektor $j$ berada di atas rata-rata daya penyebaran seluruh sektor ekonomi. Sebaliknya, bila $B L j<1$ hal tersebut berarti bahwa daya penyebaran sektor $j$ lebih rendah dari ratarata daya penyebaran seluruh sektor ekonomi.

\section{Indeks Total Keterkaitan ke Depan}

Konsep ini diartikan sebagai kemampuan suatu sektor untuk mendorong pertumbuhan produksi sektor-sektor lain yang memakai input dari sektor ini. Total keterkaitan ke depan disebut juga sebagai indeks derajat kepekaan (degree of sensitivity) yang digunakan untuk mengukur kaitan ke depan. Rumus untuk mencari nilai indeks total keterkaitan ke depan yaitu:

$$
\mathrm{FL}_{\mathrm{i}}=\frac{\mathrm{n} \sum_{\mathrm{i}=1}^{\mathrm{n}} \frac{\mathrm{v}}{\mathrm{X}} \mathrm{a}_{\mathrm{j}}}{\sum_{\mathrm{i}=1}^{\mathrm{n}} \sum_{\mathrm{j}=1}^{\mathrm{n}} \alpha_{\mathrm{ij}}}
$$

dimana:

$$
\begin{aligned}
F L i= & \text { indeks total keterkaitan ke depan } \\
& \text { sektor } i
\end{aligned}
$$

Nilai FLi dapat bernilai sama dengan 1, lebih besar 1 atau lebih kecil 1 . Bila $F L i=1$ hal tersebut berarti bahwa derajat kepekaan sektor I sama dengan rata-rata derajat kepekaan seluruh sektor ekonomi. Bila Fli > 1 hal tersebut berarti derajat kepekaan sektor $i$ lebih tinggi dari derajat kepekaan seluruh sektor ekonomi. Sebaliknya, bila $F L i<1$ hal tersebut berarti bahwa derajat kepekaan sektor $i$ dibawah rata-rata derajat kepekaan seluruh sektor ekonomi.

\section{Analisis Sektor Kunci Menggunakan Forward dan Backward Process}

Dari analisis I-O dapat dilihat sektor-sektor kunci yang memiliki backward linkages (keterkaitan ke belakang) atau disebut juga derajat kepekaan yang tinggi dan forward linkages (keterkaitan ke depan) atau daya sebar yang tinggi. Sektor yang mempunyai daya penyebaran tinggi menunjukan sektor tersebut mempunyai daya dorong yang cukup kuat dibandingkan sektor lainnya. Sedangkan sektor yang mempunyai derajat kepekaan yang tinggi menunjukkan bahwa sektor tersebut mempunyai ketergantungan yang tinggi terhadap sektor lain. Sektor kunci didefinisikan sebagai sektor yang memegang peranan penting dalam menggerakkan roda perekonomian dan ditentukan berdasarkan 
indeks total keterkaitan ke belakang dan ke depan. Sektor kunci adalah sektor yang memiliki indeks total keterkaitan ke belakang dan ke depan lebih besar dari satu.

\section{HASIL PENELITIAN DAN PEMBAHASAN}

\section{Hasil Analisis Indeks Keterkaitan Ke Depan}

Indeks total keterkaitan ke depan yang memiliki nilai lebih besar dari satu menunjukkan bahwa sektor tersebut mempunyai kemampuan yang kuat untuk mendorong pertumbuhan output industri hilirnya atau dengan kata lain kemampuan sektor tersebut untuk mendorong pertumbuhan produksi sektor-sektor lain yang memakai input dari sektor ini. Output yang dihasilkan oleh sektor tersebut merupakan komoditi intermedier, dalam artian merupakan bahan baku bagi industri-industri dan sektor-sektor perekonomian lainnya. Nilai tersebut juga menunjukkan besarnya peranan sektor industri tersebut dalam mendorong pertumbuhan perekonomian di Jawa Tengah. Dari hasil olah data tabel Input Output Jawa Tengah Tahun 2000 maka dapat diperoleh indeks derajat kepekaan atau indeks keterkaitan ke depan. Dalam
Tabel 2 menyajikan tujuh sektor yang memiliki nilai indeks total keterkaitan ke depan terbesar berdasarkan tabel input output Jawa Tengah Tahun 2000.

Dari hasil olahan data tabel input output Jawa Tengah tahun 2000, sektor industri lainnya memiliki nilai indeks paling besar yaitu dengan nilai 3,14516. Nilai tersebut menunjukkan bahwa bila terjadi kenaikan permintaan akhir atas sektor-sektor lain sebesar satu unit maka sektor industri lainnya akan mengalami peningkatan output sebesar 3,14516 unit. sektor industri makanan, minuman dan tembakau sebesar 1,24356, sektor industri pengilangan minyak 1,00214. Sedangkan sektor lainnya hanya pelengkap yaitu sektor pertambangan dan penggalian yang memiliki nilai indeks total keterkaitan ke depan atau indeks daya kepekaan sebesar 1,40276 , sektor perdagangan dengan nilai 1,26291 , sektor lembaga keuangan, real estate dan jasa perdagangan sebesar 1,06582 dan sektor pengangkutan dan komunikasi sebesar 1,00164. Output yang dihasilkan oleh sektor tersebut merupakan komoditi intermedier, dalam artian merupakan bahan baku bagi industri-industri dan sektor-sektor perekonomian lainnya.

Tabel 2. Tujuh Sektor dengan Indeks Total Keterkaitan Ke Depan Terbesar Menurut Tabel Input Output Tahun 2000

\begin{tabular}{cclc}
\hline No & Kode I-O & \multicolumn{1}{c}{ Sektor } & Indeks DK \\
\hline 1 & 9 & Industri lainnya & 3,14516 \\
2 & 7 & Pertambangan dan penggalian & 1,42076 \\
3 & 13 & Perdagangan & 1,26291 \\
4 & 8 & Industri Makanan, Minuman, dan Tembakau & 1,24356 \\
5 & 16 & Lembaga Keuangan, Real Estate, dan Jasa Perusahaan & 1,06582 \\
6 & 10 & Industri Pengilangan Minyak & 1,00214 \\
7 & 15 & Pengangkutan dan Komunikasi & 1,00164 \\
\hline
\end{tabular}

Sumber: Tabel Input Output Jawa Tengah Tahun 2000, diolah. 
Tabel 3. Empat Sektor dengan Indeks Total Keterkaitan Ke Depan Terbesar Menurut Tabel Input Output Tahun 2004

\begin{tabular}{cclc}
\hline No & Kode I-O & \multicolumn{1}{c}{ Sektor } & Indeks DK \\
\hline 1 & 7 & Pertambangan dan Penggalian & 4,07757 \\
2 & 9 & Industri lainnya & 1,98493 \\
3 & 8 & Industri Makanan, Minuman, dan Tembakau & 1,17136 \\
4 & 13 & Perdagangan & 1,39055 \\
\hline
\end{tabular}

Sumber: Tabel Input Output Jawa Tengah Tahun 2004, diolah

Sedangkan dari hasil olahan data tabel input output Jawa Tengah tahun 2004, juga dapat diperoleh indeks derajat kepekaan atau indeks keterkaitan ke depan yang disajikan dalam Tabel 3.

Dari hasil olah data tabel input output Jawa Tengah tahun 2004, sektor industri lainnya yang memiliki nilai indeks total keterkaitan ke depan atau indeks daya kepekaan sebesar 1,98493, selanjutnya sektor industri makanan, minuman dan tembakau dengan nilai 1,17136 maka sektor industri pada tahun 2004 mengalami penurunan. Sedangkan sektor lainnya yang sebagai pelengkap yaitu sektor pertambangan dan penggalian memiliki nilai indeks paling besar yaitu dengan nilai 4,07757. Nilai tersebut menunjukkan bahwa bila terjadi kenaikan permintaan akhir atas sektor-sektor lain sebesar satu unit maka sektor pertambangan dan penggalian akan mengalami peningkatan output sebesar 4,07757 unit dan sektor perdagangan sebesar 1,39055. Dimana semua sektorsektor tersebut yang memiliki nilai indeks total keterkaitan ke depan lebih besar dari satu merupakan sektor-sektor yang mampu meningkatkan pertumbuhan produksi sektorsektor lain yang menggunakan input dari sektor ini.

Dari hasil olahan tabel input-output Jawa Tengah tahun 2000 dan 2004, terlihat sektor industri yang mempunyai indeks total keterkaitan ke depan pada tahun 2004 menurun dari tahun 2000. Di tahun 2000 terdapat tujuh sektor yang mempunyai indeks keterkaitan ke depan atau derajat kepekaan, antara lain sektor Industri lainnya, sektor pertambangan dan penggalian, sektor perdagangan, sektor industri makanan, minuman dan tembakau, sektor, lembaga keuangan, real estate dan jasa perusahaan, sektor industri pengilangan minyak dan sektor pengangkutan dan komunikasi. Sedangkan pada tahun 2004, hanya terdapat empat sektor yang mempunyai derajat kepekaan lebih dari satu yaitu sektor pertambangan dan penggalian, sektor industri lainnya, industri makanan minuman dan tembakau dan sektor perdagangan. Selanjutnya sektor industri lainnya pada tahun 2000 mempunyai nilai 3,14516 dan menurun secara tajam pada tahun 2004 manjadi 1,98493. Sektor industri Makanan, Minuman dan Tembakau pada tahun 2000 sebesar 1,24356 dan pada tahun 2004 meningkat menjadi 1,17136. Industri Pengilangan Minyak pada tahun 2004 tidak mempunyai indeks derajat kepekaan yang tinggi.

Pada Tabel 4 disajikan hasil indeks keterkaitan ke depan pada tahun 2000 dan 2004 sebagai perbandingan. 


\section{Hasil Analisis Indeks Keterkaitan}

\section{ke Belakang}

Indeks total keterkaitan ke belakang yang memiliki nilai lebih besar dari satu tersebut menunjukkan bahwa sektor-sektor industri mempunyai kemampuan yang kuat untuk menarik pertumbuhan output sektor hulunya. Nilai indeks lebih besar dari satu menunjukkan daya penyebaran di sektor industri berada di atas rata-rata daya penyebaran seluruh sektor perekonomian di Jawa Tengah. Dari hasil olah data tabel Input Output Jawa Tengah Tahun 2000 maka dapat diperoleh indeks daya penyebaran atau indeks keterkaitan ke belakang seperti yang disajikan dalam Tabel 5.

Sektor industri lainnya merupakan sektor yang memiliki nilai indeks keterkaitan ke belakang yang paling tinggi yaitu sebesar 1,65850, artinya apabila terjadi kenaikan permintaan akhir terhadap sektor industri lainnya sebesar satu unit maka untuk sektorsektor ekonomi lainnya yang ada di Jawa Tengah akan mengalami pertumbuhan output sebesar 1,65850 unit. Begitu juga dengan sektor-sektor industri lain yang memiliki

Tabel 4. Indeks Total Keterkaitan Ke Depan Terbesar Menurut Tabel Input Output Tahun 2000 dan 2004

\begin{tabular}{|c|c|c|c|c|c|c|c|}
\hline \multicolumn{4}{|c|}{2000} & \multicolumn{4}{|c|}{2004} \\
\hline No & $\begin{array}{c}\text { Kode } \\
\text { I-O }\end{array}$ & Sektor & Indeks DK & No & $\begin{array}{c}\text { Kode } \\
\text { I-O }\end{array}$ & Sektor & Indeks DK \\
\hline 1 & 9 & Industri lainnya & 3,14516 & 1 & 7 & $\begin{array}{l}\text { Pertambangan dan } \\
\text { Penggalian }\end{array}$ & 4,07757 \\
\hline 2 & 7 & Pertambangan dan Penggalian & 1,42076 & 2 & 9 & Industri Lainnya & 1,98493 \\
\hline 3 & 13 & Perdagangan & 1,26291 & 3 & 8 & $\begin{array}{l}\text { Industri Makanan, } \\
\text { Minuman, dan Tembakau }\end{array}$ & \\
\hline 4 & 8 & $\begin{array}{l}\text { Industri Makanan, Minuman, } \\
\text { dan Tembakau }\end{array}$ & 1,24356 & 4 & 13 & Perdagangan & \\
\hline 5 & 16 & $\begin{array}{l}\text { Lembaga Keuangan, Real } \\
\text { Estate, dan Jasa Perusahaan }\end{array}$ & 1,06582 & & & & \\
\hline 6 & 10 & Industri Pengilangan Minyak & 1,00214 & & & & \\
\hline 7 & 15 & Pengangkutan dan Komunikasi & 1,00164 & & & & \\
\hline
\end{tabular}

Sumber: Tabel Input Output Jawa Tengah Tahun 2000 dan 2004, diolah.

Tabel 5. Delapan Sektor dengan Indeks Total Keterkaitan Ke Belakang Terbesar Menurut Tabel Input Output Tahun 2000

\begin{tabular}{cclc}
\hline No & Kode I-O & \multicolumn{1}{c}{ Sektor } & Indeks DP \\
\hline 1 & 9 & Industri Lainnya & 1,65850 \\
2 & 12 & Bangunan & 1,30056 \\
3 & 11 & Listrik, Gas, dan Air Minum & 1,26897 \\
4 & 8 & Industri Makanan, Minuman, dan Tembakau & 1,22679 \\
5 & 14 & Restoran dan Hotel & 1,20395 \\
6 & 10 & Industri Pengilangan Minyak & 1,16144 \\
7 & 18 & Jasa-jasa & 1,03612 \\
8 & 15 & Pengangkutan dan Komunikasi & 1,01495 \\
\hline
\end{tabular}


nilai indeks keterkaitan ke belakang yang lebih besar dari satu antara lain sektor sektor industri makanan, minuman dan tembakau sebesar 1,22629, sektor industri pengilangan minyak sebesar 1,16144. Sektor industri yang mempunyai daya penyebaran tinggi menunjukan sektor tersebut mempunyai daya dorong yang cukup kuat dibandingkan sektor lainya.

Berdasarkan Tabel 6 maka peranan sektor industri terhadap sektor perekonomian terlihat dominan pada perekonomian Jawa Tengah. Semua kelompok sektor industri Pada tahun 2000 yaitu sektor industri makanan, minuman dan tembakau, sektor industri lainnya, sektor industri pengilangan minyak kesemuanya menjadi sektor unggulan. Sektor-sektor industri inilah yang memegang peranan penting dalam menggerakkan roda perekonomian Jawa Tengah pada tahun 2000. Sektor industri makanan, minuman dan tembakau memiliki nilai indeks daya penyebaran sebesar 1,22629 dan nilai indeks daya kepekaan sebesar 1,24356. Besaran tersebut menunjukkan apabila terjadi kenaikan permintaan akhir terhadap sektor industri makanan. minuman dan tembakau sebesar satu unit maka sektor-sektor ekonomi lainnya yang ada di Jawa Tengah akan mengalami peningkatan output sebesar 1,22629 unit. Sebaliknya, apabila terjadi kenaikan permintaan akhir atas sektor-sektor ekonomi lainnya sebesar satu unit maka sektor industri maka- nan, minuman dan tembakau akan mengalami peningkatan output sebesar 1,24356 unit. Selanjutnya industri lainnya yang memiliki nilai indeks daya penyebaran sebesar 1,65850 dan nilai indeks daya kepekaannya sebesar 3,14516. Nilai kedua indeks pada sektor industri lainnya ini menunjukkan bahwa apabila terjadi kenaikan permintaan akhir terhadap sektor industri lainnya sebesar satu unit maka sektor-sektor ekonomi lainnya yang ada di Jawa Tengah akan mengalami peningkatan output sebesar 1,65850 unit. Sebaliknya, apabila terjadi kenaikan permintaan akhir atas sektor-sektor ekonomi lainnya sebesar satu unit maka sektor listrik dan gas akan mengalami peningkatan output sebesar 3,14516 unit. Selanjutnya, industri pengilangan minyak yang memiliki nilai indeks daya penyebaran sebesar 1,11644 dan nilai indeks daya kepekaannya sebesar 1,00214. Nilai kedua indeks pada sektor industri pengilangan minyak ini menunjukkan bahwa apabila terjadi kenaikan permintaan akhir terhadap sektor industri pengilangan minyak sebesar satu unit maka sektor-sektor ekonomi lainnya yang ada di Jawa Tengah akan mengalami peningkatan output sebesar 1,11644 unit. Sebaliknya, apabila terjadi kenaikan permintaan akhir atas sektor-sektor ekonomi lainnya sebesar satu unit maka sektor industri pengilangan minyak akan mengalami peningkatan output sebesar 1,00214 unit.

\section{Tabel 6. Sektor Industri Perekonomian Jawa Tengah Menurut Tabel Input Output Jawa Tengah} Tahun 2000

\begin{tabular}{lclrr}
\hline No & Kode I-O & Sektor & Indeks DK & \multicolumn{1}{c}{ Indeks DP } \\
\hline 1 & 8 & Industri Makanan, Minuman, dan Tembakau & 1,24356 & 1,22629 \\
2 & 9 & Industri lainnya & 3,14516 & 1,65850 \\
3 & 10 & Industri Pengilangan Minyak & 1,00214 & 1,16144 \\
\hline
\end{tabular}

Sumber: Tabel Input Output Jawa Tengah Tahun 2000, diolah. 
Berdasarkan Tabel 7 hanya terdapat dua sektor perekonomian yang menjadi sektor industri perekonomian Jawa Tengah pada tahun 2004 yaitu sektor indutri makanan, minuman dan tembakau, dan sektor industri lainnya. Sektor-sektor inilah yang memegang peranan penting dalam menggerakkan roda perekonomian Jawa Tengah pada tahun 2004. Sektor industri makanan, minuman dan tembakau memiliki nilai indeks daya penyebaran sebesar 1,20178 dan nilai indeks daya kepekaan sebesar 1,17136. Besaran tersebut menunjukkan apabila terjadi kenaikan permintaan akhir terhadap sektor industri makanan, minuman dan tembakau sebesar satu unit maka sektor-sektor ekonomi lainnya yang ada di Jawa Tengah akan mengalami peningkatan output sebesar 1,20178 unit. Sebaliknya, apabila terjadi kenaikan permintaan akhir atas sektor-sektor ekonomi lainnya sebesar satu unit maka sektor indutri makanan, minuman dan tembakau akan mengalami peningkatan output sebesar 1,17136 unit. Selanjutnya industri lainnya yang memiliki nilai indeks daya penyebaran sebesar 1,42724 dan nilai indeks daya kepekaannya sebesar 1,98493. Nilai kedua indeks pada sektor industri lainnya ini menunjukkan bahwa apabila terjadi kenaikan permintaan akhir terhadap sektor industri lainnya sebesar satu unit maka sektor-sektor ekonomi lainnya yang ada di Jawa Tengah akan mengalami peningkatan output sebesar 1,98493 unit. Sebaliknya, apabila terjadi kenaikan permintaan akhir atas sektor-sektor ekonomi lainnya sebesar satu unit maka sektor listrik dan gas akan mengalami peningkatan output sebesar 1,42724 unit. Sedangkan sektor industri pengilangan minyak pada tahun 2004 tidak menjadi sektor kunci. Dalam pembangunan di Jawa Tengah untuk memacu pertumbuhan ekonomi di Jawa Tengah, maka sektor-sektor tersebut layak untuk diprioritaskan. Hal ini dikarenakan sektor-sektor tersebut memiliki daya dorong yang kuat terhadap penciptaan sektor-sektor ekonomi lainnya dan juga memiliki sensitivitas yang tinggi terhadap perubahan permintaan akhir dari sektorsektor ekonomi lainnya.

Pada tahun 2000 terdapat empat sektor yang menjadi sektor industri perkonomian Jawa Tengah antara lain sektor industri makanan, minuman dan tembakau, sektor industri lainnya, sektor industri pengilangan minyak, dan sektor pengangkutan dan komunikasi. Sedangkan pada tahun 2004 hanya menjadi dua sektor yaitu sektor industri makanan, minuman dan tembakau dan sektor industri lainnya. Dalam Tabel 8 disajikan perbandingan sektor industri Jawa Tengah pada tahun 2000 dan 2004.

Interpretasi ekonomi dimaksudkan untuk menginterpretasikan hasil analisis berdasarkan ilmu-ilmu ekomomi terhadap keseluruhan hasil analisis. Dari analisis mengenai sektor industri perekonomian Jawa Tengah

Tabel 7. Sektor Industri Perekonomian Jawa Tengah

\begin{tabular}{cclcc}
\hline No & Kode I-O & \multicolumn{1}{c}{ Sektor } & Indeks DK & Indeks DP \\
\hline 1 & 8 & Industri Makanan, Minuman, dan Tembakau & 1,17136 & 1,20178 \\
2 & 9 & Industri Lainnya & 1,98493 & 1,42724 \\
\hline
\end{tabular}

Menurut Tabel Input Output Jawa Tengah Tahun 2004 
Tabel 8. Sektor Industri yang Menjadi Sektor Kunci Perekonomian Jawa Tengah Menurut Tabel Input Output Jawa Tengah Tahun 2000 dan 2004

\begin{tabular}{cccccccc}
\hline \multicolumn{2}{c}{2004} & & & \multicolumn{3}{c}{2000} \\
\hline Kode I-O & Sektor & $\begin{array}{c}\text { Indeks } \\
\text { DK }\end{array}$ & Indeks DP & Kode I-O & Sektor & $\begin{array}{c}\text { Indeks } \\
\text { DK }\end{array}$ & $\begin{array}{c}\text { Indeks } \\
\text { DP }\end{array}$ \\
\hline 8 & $\begin{array}{l}\text { Industri } \\
\text { Makanan, } \\
\text { Minuman, dan } \\
\text { Tembakau }\end{array}$ & 1,17136 & 1,20178 & 8 & $\begin{array}{l}\text { Industri Makanan, } \\
\text { Minuman, dan } \\
\text { Tembakau }\end{array}$ & 1,24356 & 1,22629 \\
9 & Industri Lainnya & 1,98493 & 1,42724 & 9 & Industri Lainnya & 3,14516 & 1,65850 \\
& & & 10 & $\begin{array}{l}\text { Industri } \\
\text { Pengilangan } \\
\text { Minyak }\end{array}$ & 1,00214 & 1,16144 \\
\hline
\end{tabular}

Sumber: Tabel Input Output Jawa Tengah Tahun 2000 dan 2004, diolah

tahun 2000 dan 2004 maka dapat dilakukan interpretasi ekonomi berdasarkan hasil analisis nilai tambah bruto, analisis indeks keterkaitan ke belakang, analisis indeks keterkaitan ke depan dan analisis sektor kunci.

Komponen upah dan gaji sebagai pembentuk nilai tambah bruto pada tahun 2000 yang diciptakan oleh kegiatan ekonomi di Jawa Tengah mencapai Rp. 33.893.355,43 juta atau sebesar 28,78 persen dari total Rp.117.750.498,96 juta di tahun 2000 dan meningkat sebesar Rp. 58.450.517,29 juta dan memberikan kontribusi 30,21 persen pada tahun 2004 dengan nilai total Rp.193.435.263,05 juta. Namun ternyata komponen upah dan gaji ternyata relatif lebih rendah bila dibandingkan dengan surplus usaha, surplus usaha yang diterima oleh pengusaha satu setengah kali lebih besar dibandingkan komponen upah dan gaji. Komponen surplus usaha memberikan kontribusi sebesar 57,86 persen atau senilai Rp. 68.133.212,52 juta pada tahun 2000, dan meskipun pada tahun 2004 menurun menjadi 51,92 persen dengan nilai Rp.100.442.999,19 juta. Padahal upah dan gaji merupakan satu- satunya komponen nilai tambah yang bisa langsung diterima oleh pekerja. Surplus usaha sendiri belum tentu dapat langsung dinikmati oleh masyarakat, karena surplus usaha tersebut sebagian ada yang tersimpan atau ditanam di perusahaan dalam bentuk laba yang ditahan. Dalam surplus usaha termasuk juga bagian pendapatan dari tenaga kerja yang tidak dibayar.

Nilai indeks keterkaitan ke depan atau indeks daya kepekaan pada tahun 2000 terdapat tujuh sektor yang mempunyai indeks keterkaitan ke depan atau derajat kepekaan, antara lain sektor Industri lainnya, sektor pertambangan dan penggalian, sektor perdagangan, sektor industri makanan, minuman dan tembakau, sektor, lembaga keuangan, real estate dan jasa perusahaan, sektor industri pengilangan minyak dan sektor pengangkutan dan komunikasi.

Sedangkan pada tahun 2004, hanya terdapat empat sektor yang mempunyai derajat kepekaan lebih dari satu yaitu sektor pertambangan dan penggalian, sektor industri lainnya, industri makanan minuman dan tembakau dan sektor perdagangan. Sektor 
Industri lainnya memberikan kontribusinya yang paling tinggi dibandingkan dengan sektor lainnya pada tahun 2000 sebesar 3,14516. Nilai ini berarti menunjukkan pengaruh sektor industri lainnya apabila terjadi kenaikan permintaan akhir atas sektorsektor lain sebesar satu juta maka sektor industri lainnya akan mengalami peningkatan output sebesar 3,14516. Sedangkan pada tahun 2004 sektor yang memiliki indeks keterkaitan ke depan atau daya kepekaan tinggi adalah sektor yang pertambangan dan penggalian sebesar 4,07757. Nilai ini berarti menunjukkan pengaruh sektor pertambangan dan penggalian apabila terjadi kenaikan permintaan akhir atas sektor-sektor lain sebesar satu juta maka sektor pertambangan dan penggalian akan mengalami peningkatan output sebesar 4,07757. Output yang dihasilkan merupakan komoditi intermedier, dalam artian merupakan bahan baku bagi industri-industri dan sektor-sektor perekonomian lainnya.

Nilai indeks keterkaitan ke belakang atau daya penyebaran pada tahun 2000 terdapat delapan sektor antara lain industri lainnya, bangunan listrik, gas dan air minum, industri makanan, minuman dan tembakau, restoran dan hotel, industri pengilangan minyak, jasa-jasa, pengangkutan dan komunikasi. Sektor yang mempunyai nilai indek penyebaran paling tinggi pada tahun 2000 adalah sektor Industri lainnya yang memberikan kontribusi sebesar 1,65850 yang artinya apabila terjadi kenaikan permintaan akhir terhadap sektor industri lainnya sebesar satu unit maka untuk sektor-sektor ekonomi lainnya yang ada di Jawa Tengah akan mengalami pertumbuhan output sebesar 1,65850 unit. Sedangkan pada tahun 2004, sektor industri pengilangan minyak merupakan sektor yang memiliki nilai indeks keterkaitan ke belakang yang paling tinggi yaitu sebesar 2,30278, artinya apabila terjadi kenaikan permintaan akhir terhadap sektor industri pengilangan minyak sebesar satu unit maka untuk sektor-sektor ekonomi lainnya yang ada di Jawa Tengah akan mengalami pertumbuhan output sebesar 2,30278 unit. Sektor yang mempunyai daya penyebaran tinggi menunjukan sektor tersebut mempunyai daya dorong yang cukup kuat dibandingkan sektor lainnya.

Peranan sektor industri dalam dalam tabel input output Jawa Tengah pada tahun 2000 dan 2004 mempunyai peranan yang cukup signifikan dalam proses produksi. Terlihat dari beberapa sektor industri menjadi sektor kunci perekonomian Jawa Tengah. Pada tahun 2000 sektor industri makanan, minuman, dan tembakau menyumbang sebesar Rp. 27.744.377,35 juta dengan indeks keterkaitan ke depan sebesar 1,24356 dan ke belakang sebesar 1,22629 atau sebesar 13,4 persen dari jumlah output. Selanjutnya industri lainnya menyumbang Rp. 27.901.202,3 juta dengan indeks keterkaitan ke depan sebesar 3,14516 dan ke belakang sebesar 1,65850 atau sebesar 13,48 persen dari jumlah output. Sedangkan sektor industri penanggulangan minyak menyumbang $\mathrm{Rp}$. 11.101.830,81 juta dengan indeks keterkaitan ke depan sebesar 1,00214 dan ke belakang sebesar 1,16144 atau sebesar 5,36 persen dari jumlah output. Dalam hasil analisis pada tahun 2004 sektor industri makanan, minuman dan tembakau menyumbang sebesar Rp. 47.409.368,92 juta dengan indeks keterkaitan ke depan sebesar 1.17136 dan ke belakang sebesar 1.20178 atau sebesar 22,9 persen dari jumlah output. Selanjutnya industri lainnya menyumbang $\mathrm{Rp}$. 
49.280.413,96 juta dengan indeks keterkaitan ke depan sebesar 1.98493 dan ke belakang sebesar 1.42724 atau sebesar 23,8 persen dari jumlah output. Pada 2004 industri pengilangan minyak tidak termasuk menjadi sektor kunci karena mengalami penurunan dari tahun 2000.

\section{KESIMPULAN}

Berdasarkan hasil analisis input output dengan menggunakan Tabel Input Output Jawa Tengah tahun 2000 dan tahun 2004 tentang peranan sektor industri terhadap perekonomian Jawa Tengah tahun 2000 dan tahun 2004 maka dapat ditarik kesimpulan sebagai berikut:

1. Komponen pembentuk nilai tambah bruto dengan peranan terbesar adalah surplus usaha. Pada tahun 2000 peranan komponen ini dalam pembentukan nilai tambah di Jawa Tengah adalah sebesar 57,86 persen dengan nilai sebesar Rp.68.133.212,52 juta dan pada tahun 2004 menurun menjadi 51,92 persen dengan nilai sebesar Rp.100.442.999,19 juta.

2. Jumlah permintaan akhir yang tercipta masing-masing pada tahun 2000 dan 2004 adalah sebesar Rp. 272.703.047 juta dan Rp.170.021.068 juta. Komponen konsumsi rumah tangga menjadi pengguna PDRB terbesar selama kurun waktu tersebut. Bila pada tahun 2000 sebanyak 55,38 persen PDRB Jawa Tengah digunakan untuk memenuhi konsumsi rumah tangga maka pada tahun 2004 meningkat menjadi sekitar 65,25 persen. Sebaliknya, terjadi penurunan persentase penggunaan PDRB untuk pembentukan modal tetap bruto. Pada tahun 2000 sebanyak 17,13 persen PDRB digunakan untuk investasi melalui pembentukan modal tetap bruto namun pada tahun 2004 persentasenya turun menjadi hanya sebesar 16,81 persen. Sementara itu ekspor netto Jawa Tengah mengalami sedikit peningkatan. Pada tahun 2000 komponen ekspor netto PDRB menunjukkan peranan sebesar 8,50 persen namun pada tahun 2004 peranannya meningkat cukup signifikan, yakni menjadi 10,63 persen.

3. Nilai indeks keterkaitan ke depan atau indeks daya kepekaan pada tahun 2000 terdapat tujuh sektor yang mempunyai indeks keterkaitan ke depan atau derajat kepekaan, antara lain sektor Industri lainnya, sektor pertambangan dan penggalian, sektor perdagangan, sektor industri makanan, minuman dan tembakau, sektor, lembaga keuangan, real estate dan jasa perusahaan, sektor industri pengilangan minyak dan sektor pengangkutan dan komunikasi. Sedangkan pada tahun 2004, hanya terdapat empat sektor yang mempunyai derajat kepekaan lebih dari satu yaitu sektor pertambangan dan penggalian, sektor industri lainnya, industri makanan minuman dan tembakau dan sektor perdagangan. Sektor Industri lainnya memberikan kontribusinya yang paling tinggi dibandingkan dengan sektor lainnya pada tahun 2000 sebesar 3,14516. Nilai ini berarti menunjukkan pegaruh sektor industri lainnya apabila terjadi kenaikan permintaan akhir atas sektor-sektor lain sebesar satu juta maka sektor industri lainnya akan mengalami peningkatan output sebesar Rp. 3,14516 juta. Sedangkan pada tahun 2004 sektor yang memiliki indeks keterkaitan ke 
depan atau daya kepekaan tinggi adalah sektor yang pertambangan dan penggalian sebesar 4,07757. Nilai ini berarti menunjukkan pengaruh sektor pertambangan dan penggalian apabila terjadi kenaikan permintaan akhir atas sektorsektor lain sebesar satu juta maka sektor pertambangan dan penggalian akan mengalami peningkatan output sebesar Rp. 4,07757 juta.

4. Nilai indeks keterkaitan ke belakang atau daya penyebaran pada tahun 2000 terdapat delapan sektor antara lain industri lainnya, bangunan listrik, gas dan air minum, industri makanan, minuman dan tembakau, restoran dan hotel, industri pengilangan minyak, jasa-jasa, pengangkutan dan komunikasi. Sektor yang mempunyai nilai indeks penyebaran paling tinggi pada tahun 2000 adalah sektor industri lainnya yang memberikan kontribusi sebesar 1,65850 yang artinya apabila terjadi kenaikan permintaan akhir terhadap sektor industri lainnya sebesar satu unit maka untuk sektor-sektor ekonomi lainnya yang ada di Jawa Tengah akan mengalami pertumbuhan output sebesar 1,65850 unit. Sedangkan pada tahun 2004, sektor industri pengilangan minyak merupakan sektor yang memiliki nilai indeks keterkaitan ke belakang yang paling tinggi yaitu sebesar 2,30278, artinya apabila terjadi kenaikan permintaan akhir terhadap sektor industri pengilangan minyak sebesar satu unit maka untuk sektor-sektor ekonomi lainnya yang ada di Jawa Tengah akan mengalami pertumbuhan output sebesar 2,30278 unit.

5. Sektor kunci perekonomian Jawa Tengah pada tahun 2000 yaitu sektor indutri makanan, minuman dan tembakau, sektor industri lainnya, sektor industri pengilangan minyak dan sektor pengangkutan dan komunikasi. Sektor-sektor inilah yang memegang peranan penting dalam menggerakkan roda perekonomian Jawa Tengah pada tahun 2000. Sedangkan tahun 2004 hanya terdapat dua sektor perekonomian yang menjadi sektor kunci perekonomian Jawa Tengah yaitu sektor industri makanan, minuman dan tembakau, dan sektor industri lainnya. Ini memperlihatkan bahwa terjadi penurunan dalam perekonomian Jawa Tengah pada tahun 2004 bila dibandingkan dengan tahun 2000.

6. Peranan sektor industri dalam dalam tabel input output Jawa Tengah pada tahun 2000 dan 2004 mempunyai peranan yang cukup signifikan dalam proses produksi. Terlihat dari beberapa sektor industri menjadi sektor kunci perekonomian Jawa Tengah. Pada tahun 2000 sektor industri makanan, minuman dan tembakau menyumbang sebesar Rp.27.744.377,35 juta dengan indeks keterkaitan ke depan sebesar 1,24356 dan ke belakang sebesar 1,22629 atau sebesar 13,4 persen dari jumlah output. Selanjutnya industri lainnya menyumbang Rp.27.901.202,3 juta dengan indeks keterkaitan ke depan sebesar 3,14516 dan ke belakang sebesar 1,65850 atau sebesar 13,48 persen dari jumlah output. Sedangkan sektor industri pengilangan minyak menyumbang Rp. 11.101.830,81 juta dengan indeks keterkaitan ke depan sebesar 1,00214 dan ke belakang sebesar 1,16144 atau sebesar 5,36 persen dari jumlah output. Dalam hasil analisis pada tahun 2004 sektor industri makanan, 
minuman dan tembakau menyumbang sebesar Rp.47.409.368,92 juta dengan indeks keterkaitan ke depan sebesar 1.17136 dan ke belakang sebesar 1.20178 atau sebesar 22,9 persen dari jumlah output. Selanjutnya industri lainnya menyumbang Rp.49.280.413,96 juta dengan indeks keterkaitan ke depan sebesar 1.98493 dan ke belakang sebesar 1.42724 atau sebesar 23,8 persen dari jumlah output. Pada 2004 industri pengilangan minyak tidak termasuk menjadi sektor kunci karena mengalami penurunan dari tahun 2000.

Dari kesimpulan di atas, dapat dikemukakan beberapa saran yang diharapkan dapat bermanfaat bagi pengambilan kebijakan pemerintah dan bagi penelitian selanjutnya.

1. Sektor industri makanan, minuman dan tembakau, dan sektor industri lainnya perlu mendapat perhatian dari pemerintah Jawa Tengah karena sektor industri makanan, minuman dan tembakau, sektor industri lainnya sangat berperan dalam memacu pertumbuhan ekonomi di Jawa Tengah pada tahun 2000 dan 2004. Sektor industri makanan, minuman dan tembakau, dan sektor industri lainnya memiliki daya dorong yang kuat terhadap penciptaan sektor-sektor ekonomi lainnya dan juga memiliki sensitivitas yang tinggi terhadap perubahan permintaan akhir dari sektor-sektor ekonomi lainnya.

2. Pemerintah provinsi Jawa Tengah juga harus memberikan perhatian lebih terhadap sektor industri pengilangan minyak yang pada tahun 2000 menjadi sektor kunci namun pada tahun 2004 sektor tersebut tidak lagi menjadi sektor kunci.
3. Sektor-sektor lain yang pada tahun 2000 dan 2004 memiliki indeks keterkaitan ke depan atau daya kepekaan yang tinggi seperti sektor industri lainnya, sektor pertambangan dan penggalian, sektor perdagangan, sektor, lembaga keuangan, real estate dan jasa perusahaan di usahakan juga agar menjadi sektor kunci pada tahun-tahun selanjutnya, dengan memberikan regulasi khusus dari pemerintah Jawa Tengah.

4. Untuk penelitian selanjutnya sebaiknya menambahkan beberapa analisis lagi sehingga benar-benar dapat menganalisis sebuah peranan sektor ekonomi terhadap perekonomian Jawa Tengah.

\section{DAFTAR PUSTAKA}

Badan Pusat Statistik. 2002. Analisis Lanjutan Tabel Input-Output DKI Jakarta 2000: Tinjauan Perekonomian. BPS: DKI Jakarta.

Badan Pusat Statistik. 2000. Kerangka Teori dan Analisis Tabel Input Output. BPS: DKI Jakarta.

Badan Pusat Statistik. 2000. Tabel Input Output Indonesia Tahun 2000. BPS: DKI Jakarta.

Badan Pusat Statistik. 2003. Tabel Input Output Indonesia Updating 2003. BPS: DKI Jakarta.

Badan Pusat Statistik. 2000. Tabel Input Output Jawa Tengah Tahun 2000. BPS: Jawa Tengah.

Badan Pusat Statistik. 2004. Tabel Input Output Jawa Tengah Tahun 2004. Badan Pusat Statistik: Jawa Tengah. 
Badan Pusat Statistik. 2003. Statistik Sosial dan Kependudukan Jawa Tengah. Hasil Susenas 2003. Semarang: BPS Jawa Tengah.

Arsyad, Lincoln. 1999. Ekonomi Pembayaran. Yogyakarta: Bagian Penerbitan STIE YKPN.

Jhingan, M.L. 1998. Beberapa Masalah Perencanaan Pembangunan Daerah. Jakarta: Rajawali Press.

Miller, Ronald E, dan Peter H. Blair. 1999. Input Output Analysis: Foundation and Extensions, New Jersey: Prentice Hall.
Nazara, Suahasil. 1997. Analisis Input Output. Jakarta: Lembaga Penerbitan FE UI.

Kamaluddin, R. 1987. Beberapa Aspek Pembangunan Nasional dan Pembangunan Daerah. Jakarta: LPFE-UI.

Tambunan, Tulus, 2001. Industri di Negara Berkembang Kami Indonesia. Jakarta: Ghalia. 